\title{
Pengaruh Religiusitas terhadap Kematangan Karier Pustakawan Kajian Empiris pada Pendidikan Tinggi Keagamaan Islam di Daerah Istimewa Yogyakarta
}

\author{
Sungadi \\ Perpustakaan Universitas Islam Indonesia \\ email: sungadi@uii.ac.id
}

\begin{abstract}
Abstrak
Adanya kemampuan pemahaman agama (religiusitas) yang memadai, pustakawan dimungkinkan memiliki peran penting terhadap pegembangan dan pembinaan karier pustakawan. Penelitian ini bertujuan untuk membuktikan secara empiris pengaruh religiusitas terhadap kematangan karier pustakawan.Manfaat penelitian adalah untuk memberikan pemahaman terhadap nilai-nilai Islam dalam menjalani profesi pustakawan agar memiliki sifat amanah, jujur, rasa optimis dan bertanggung jawab sehingga kematangan karier akan dapat tercapai. Riset dilakukan pada Pendidikan Tinggi Keagamaan Islam (PTKI) di Daerah Istimewa Yogyakarta (DIY) dengan mengambil seluruh populasi (82 orang) pustakawan sebagai responden penelitian, namun dari hasil pengumpulan data hanya 78 angket yang kembali secara lengkap dan 4 angket kembali tidak lengkap, sehingga jumlah responden penelitian menjadi 78. Metode penelitian bersifat kuantitatif, pengumpulan data primer dan skunder. Data primer diperoleh melalui penyebaran angket kepada responden dan data skunder diperoleh dari dokumen yang ada di PTKI DIY. Analisis data menggunakan analisis deskriptif dan regeresi sederhana. Hasil riset menunjukkan bahwa persepsi Pustakawan Pendidikan Tinggi Keagamaan Islam (PTKI) di DIY terhadap variabel penelitian dalam kategori baik sampai dengan kategori sangat baik. Persepsi pada variabel religiusitas pada posisi sangat tinggi/sangat baik dan variabel kematangan karier dalam kondisi tinggi/ baik. Dari analisis regresi sederhana dapat dinyatakan bahwa persepsi Pustakawan Pendidikan Tinggi Keagamaan Islam (PTKI) di DIY terhadap Religiusitas (X) berpengaruh positif terhadap kematangan karier (Y) terdapat nilai pengaruh sebesar 0,292 dengan signifikansi 0,009<0,05, artinya menerima hipotesis. Secara umum, dalam penelitian ini memberikan kesimpulan bahwa secara teoritik religiusitas berpengaruh terhadap kematangan karier Pustakawan Pendidikan Tinggi Keagamaan Islam (PTKI) di DIY.
\end{abstract}

\author{
Kata kunci : \\ Religiusitas, \\ Kematangan Karier, \\ Pustakawan, \\ pendidikan tinggi
}

\section{A. PENDAhuluan}

Tantangan yang dihadapi pustakawan dari waktu ke waktu semakin kompleks. Hal ini disebabkan oleh adanya perubahan berbagai bentuk informasi dan semakin beragamnya kebutuhan informasi bagi penikmat ilmu pengetahuan, mulai dari informasi dalam bentuk teks tercetak maupun non cetak, gambar, suara, dan gabungan antara gambar dengan suara, dan lain-lain. Agar dapat memenuhi dari berbagai kebutuhan pemustaka tersebut, pustakawan dituntut untuk memiliki skill dan kemampuan dalam bidang teknologi dan informasi. Para penggemar informasi dan ilmu pengetahuan dapat memenuhi kebutuhannya sepanjang hayat lewat perpustakaan. Agar dapat tercapai pemenuhan kebutuhan informasi tersebut, perpustakaan sudah seharusnya dapat menyediakan sumber bacaan yang beragam dan memadai sehingga keinginan pembaca dapat terpenuhi. Keragaman sumber bacaan tersebut akan dapat terpenuhi sangat dipengaruhi oleh kinerja pustakawan. Kinerja pustakawan dalam rangka mengembangkan karier sehingga dapat dicapai kematangan karier sangat terbuka lebar. Masalah ini dapat dibuktikan adanya peluang bagi pustakawan yang dapat naik pangkat dalam dua tahun sekali dan kenaikan jabatan pada setiap tahun sekali (Perpusnas RI, 2015). 
Hasil riset pendahuluan pada bulan Mei sampai dengan Agustus 2016, terbukti bahwa permasalahan yang dialami Pustakawan Pendidikaan Tinggi Keagamaan Islam (PTKI) Daerah Istimewa Yogyakarta adalah: (1) kurangnya persiapan pada saat akan memasuki dunia kepustakawanan; (2) sebanyak $90.63 \%$ di awal pengangkatan dengan cara inpassing; (3) ditemukan sebanyak 44,03\% pustakawan $<4$ tahun tidak mengurus kenaikan pangkat dan jabatan; dan 13,84\% mendapatkan sanksi diberhentikan sementara menjadi Pustakawan; (4) ditemukan data 29,56\% pustakawan berijazah SMA sederajat dan non ilmu perpustakaan; (5) Pada saat dilakukan penelitian, pustakawan PTKI DIY belum ada yang mencapai jabatan sebagai Pustakawan Utama.

Dari hasil penelitian awal di atas menunjukkan bahwa masalah yang dihadapi oleh Pustakawan Perguruan Tinggi DIY saat ini adalah sejumlah $90,63 \%$ di awal pengangkatan dengan cara inpassing. Hal ini berdampak pada pustakawan yang mengalami masa krisis dan kritis jabatan sebesar $57,87 \%$ (terdiri dari $44,03 \%$ tidak mampu mengurus kenaikan pangkat dan jabatan dan 13,84\% dihentikan sementara statusnya sebagai pustakawan).

Secara akademik, riset ini dipandang sebagai hal yang urgent untuk dilaksanakan dalam rangka terbentuknya pustakawan yang memiliki normanorma moral (akhlaq karimah) dan norma-norma agama (religiusitas). Sementara itu secara praktis, riset ini memiliki nilai yang vital untuk dilakukan, dengan mempertimbangkan masih sangat terbatasnya tema yang mengkaji kematangan karier pustakawan, dan bisa dinyatakan belum adanya peneliti yang melakukan penyelidikan masalah ini. Dengan mempertimbangkan masih terbatasnya bahkan bisa dinyatakan belum ditemukan penelitian kematangan karier pustakawan, sehingga masalah ini dirasa perlu dan patut untuk dikaji lebih mendalam.
Berangkat dari latar belakang diatas, peneliti akan melakukan kajian tentang "Pengaruh Religiusitas terhadap Kematangan Karier Pustakawan: Studi Empiris pada Pendidikaan Tinggi Keagamaan Islam di Daerah Istimewa Yogyakarta".

Penelitian ini akan mengkaji dan menganalisis terhadap masalah penelitian antara lain meliputi: (1) Kondisi religiusitas pustakawan pada Perpustakaan Pendidikaan Tinggi Keagamaan Islam di Daerah Istimewa Yogyakarta. (2) Kondisi tingkat kematangan karier pustakawan pada Perpustakaan Pendidikan Tinggi Keagamaan Islam di Daerah Istimewa Yogyakarta. (3) Untuk menguji apakah religiusitas berpengaruh terhadap kematangan karier pustakawan.

\section{B. KAJIAN PUSTAKA}

Terdapat tiga istilah yang mempunyai makna sama dan dapat saling menggantikan, yaitu agama, din, religi. Istilah riligi (religion, bahasa Inggris) dan din (ad-diin, bahasa Arab) mempunyai makna yang sepadan dengan istilah agama. Secara etimologis punya arti sendiri-sendiri, namun secara terminologis dan teknis tiga istilah di atas memiliki arti dan makna yang sama, yaitu mengikat jadi satu (Anshari, 1987). Tentang pengertian agama, Syaltut (Shihab, 1992) mengatakan bahwa agama adalah ketetapan Allah yang diwahyukan kepada para Nabi-Nya untuk menjadi pedoman hidup manusia. Selanjutnya Glock dan Stark (1988) menandaskan bahwa agama adalah sistem simbol, sistem keyakinan, sistem nilai, dan sistem perilaku yang terlembagakan, yang semuanya berpusat persoalan-persoalan yang dihayati sebagai sesuatu yang paling maknawai. Pengertian agama yang dibuat oleh Syaltut meliputi agama-agama yang samawi atau agama langit (agama yang diturunkan Tuhan). Sementara pengertian agama versi Glock dan Stark meliputi semua agama ditambah dengan sistem keyakinan atau sistem kepercayaan 
lain. Dari pengertian agama dan religi dapat juga disamakan pengertian keberagamaan dan religiusitas (religiousity). Glock dan Stark mengartikan religiusitas sebagai keyakinan akan ajaran agama tertentu dan dampak dari ajaran agama itu dalam kehidupan sehari-hari dalam kehidupan masyarakat. Dengan bahasa yang lebih sederhana, Dister (1994) mengartikan religiusitas sebagai internalisasi agama dalam diri seseorang. Dikatakannya, orang yang beragama akan merasakan adanya kewajiban tak bersyarat terhadap zat yang diyakininya sebagai sumber kebaikan. Telaah kritis yang diberikan kepada pengertian religiusitas menurut Glock dan Stark (1988) adalah penekanannya kepada keyakinan dan dampak dari keyakinan itu. Deskripsi tentang dampak dari keyakinan kurang dijelaskan secara lebih terinci. Sementara itu, kritik terhadap pandangan Dister (1990) adalah kurang memberikan deskripsi tentang area keberagamaan. Oleh karena itu, menarik untuk dicermati pengertian religiusitas menurut Ancok dan Suroso (2011) serta menurut Nashori dan Mucharam (2002). Ancok dan Suroso (2011) mengartikan religiusitas adalah tingkat pengetahuan, keyakinan, pelaksanaan, dan penghayatan seseorang atas ajaran agama yang diyakininya. Senada dengan pandangan di atas, Nashori dan Mucharam (2002) mengartikan religiusitas sebagai sejauh mana pengetahuan, seberapa kuat keimanan, seberapa kuat implementasi ibadah dan akhlak, serta seberapa dalam pemahaman atas agama yang dipeluknya. Dalam tulisan ini, pengertian religiusitas mengacu kepada penjelasan Ancok dan Suroso (2011) serta Nashori dan Mucharam (2002). Ahli-ahli Islam dan psikologi tertarik untuk memberikan penjelasan tentang dimensi-dimensi religiusitas. Ahli-ahli Islam seperti Anshari (1987) mengungkapkan bahwa dimensi keberagamaan Islam meliputi akidah, ibadah, dan akhlak. Sementara Abdullah (2002) mengungkapkan religiusitas seseorang ada tiga dimensi, yaitu Iman, Islam, dan Ihsan. Di sisi lain, ahli-ahli psikologi agama kontemporer pada umumnya bepandangan bahwa dimensi religiusitas meliputi keyakinan, ritual, konsekuensial, eksperiensial, dan intelektual. Glock dan Stark (1988) serta Paloutzian (1996) berpandangan bahwa dimensi religiusitas terdiri atas lima, yaitu keyakinan (the ideological dimension, religious belief), peribadatan atau praktik agama (the ritualistic dimension, religious practice), pengalaman (consequential dimension, religious effect), penghayatan (the experiential dimension, religious feeling), dan pengetahuan agama (the intellectual dimension, religious knowledge).

Ahli Islam yang memahami psikologi seperti Rakhmat (1997; 2003) dan ahli psikologi yang memahami Islam seperti Ancok dan Suroso (2011) mencoba mencari jalan tengah atas dimensi keagamaan ini. Rakhmat percaya bahwa pemahaman terhadap religiousitas seseorang harus memahami aspek konseptual dan aktual. Salah satu bagian dari aspek konseptual religiousitas adalah dimensi intelektual. Dengan demikian Rakhmat (1997; 2003) mengungkapkan bahwa semestinya keberagamaan meliputi dimensi-dimensi ideologis, ritualistik, konsekuensial atau sosial, eksperiensial, dan intelektual. Dimensi keberagamaan ini dapat dipakai untuk menjelaskan religiousitas dengan latar belakang agama apapun, termasuk religious Islam. Di sisi lain Ancok dan Suroso (2011) mengungkapkan bahwa pemahaman religiusitas pemeluk agama harus memperhatikan karakteristik khas yang ada di kalangan agama tersebut. Untuk memahami keberagamaan umat Islam, maka dimensi-dimensinya juga yang bersumber dari ajaran Islam. Disamping dimensi-dimensi akidah, ibadah, akhlak, dan ihsan, semestinya dimasukkan juga dimensi ilmu agama. Menurut Ancok dan Suroso, dimensi ilmu juga penting karena memberikan pengaruh terhadap dimensi-dimensi lain. Ilmu Agama yang mantap 
mengantarkan individu lebih kokoh akidahnya, luas, mantap ibadahnya, lebih bersemangat dalam akhlaknya, serta memungkinkan memiliki pengalaman kedekatan dengan Tuhan (baca: Ihsan) lebih banyak.

Savickas (2005) menyatakan bahwa career maturity dapat dinyatakan dengan adaptasi profesi, yaitu kewaspadaan seseorang dan pemanfaatan resources yang tersedia sebagai penunjang dalam membina karier yang sedang diemban, perubahan profesi, dan problematika tugas keprofeseian. Career maturity bagi mahasiswa, bisa didefinisikan kewaspadaan mahasiswa dalam menentukan alternatif profesi secara realistis. Super (dalam Sharf, 2006) menyatakan bahwa career maturity merupakan sikap seseorang dalam mengenali, menentukan, mempersiapkan, dan mempraktikkan haluan profesi yang cocok dengan umur rerata dalam fase pertumbuhan kariernya. Dari dua pengertian tersebut dapat diambil kesimpulan bahwa kematangan karier individu dapat diartikan sebagai kesiagaan seseorang dalam menentukan dan memutuskan dengan akurat. Lock (2005) menyatakan bahwa career maturity adalah kecakapan seseorang dalam menetapkan profesi yang akurat, mengetahui bahwa opsi profesi perlu ditetapkan, dan jenjang dari opsi perorangan yang efisien dan konstan selama-lamanya. Luzzo dan Savickas (dalam Levinson, Caswell, \& Kiewra, 1998) menyatakan bahwa career maturity merupakan kecakapan seseorang dalam mendapatkan keinginan yang diperlukan, seperti knowledge dan skill untuk menyiapkan opsi profesi yang berkeadaan realistis, mampu menetapkan pilihan terhadap profesi yang cocok dengan informasi yang diperoleh dan fase pertumbuhan karier perorangan tersebut. Hal itu, dapat dinyatakan bahwa career maturity merupakan kecakapan mahasiswa dalam mengetahui kemampuan pribadinya, sehingga dapat membuat persiapan dalam menentukan opsi profesi yang realistis, yang kesudahannya bisa menetapkan serta memutuskan terhadap profesi yang akan dikerjakan setelah menyelesaikan pendidikannya.

Dari berbagai pengertian tersebut, dapat dipahami bahwa career maturity merupakan kecakapan seseorang dalam mengetahui potensi diri yang dimilikinya dan menelaah opsi-opsi prodi/karier yang diinginkan untuk bisa menentukan pilihan profesi dengan akurat, selaras dengan fase pertumbuhan seseorang.

Teori Crites dalam (Gonzalez, 2008) ada dua dimensi dalam kematangan karier, yaitu dimensi sikap dan dimensi kognitif. Dimensi sikap meliputi: keterlibatan, bimbingan, kebebasan, pilihan, dan komitmen. Sementara dimensi kognitif terdiri dari: penyelesaian masalah, perencanaan, seleksi sasaran, dan penilaian kinerja sendiri. Teori Super masih dalam (Gonzalez, 2008) menjelaskan bahwa ada dua dimensi besar dalam kematangan karier, sama dengan teori Crites yaiu dimensi sikap dan dimensi kognitif. Perbedaan terletak pada sub dimensi, dimana sub dimensi kematangan karier menurut Super adalah terdiri dari: (1) sikap, meliputi perencanaan karier dan eksplorasi karier; (2) kognitif, meliputi pembuatan keputusan karier, informasi pengembangan karier, pengetahuan tentang dunia kerja, dan informasi tentang pekerjaan pilihan. Masih menurut Super yang dikutip oleh Sharf (2006) yang menyatakan bahwa kematangan karier ditentukan oleh 2 (dua) dimensi yaitu dimensi sikap (attitude) dan dimensi pengetahuan dan keterampilan (knowledge and skill). Dimensi attitude terdiri dari 2 (dua) indikator yaitu: perencanaan karier dan eksplorasi karier. Sementara dimensi knowledge and skill terbagi dalam 
tiga (3) indikator antara lain: pengambilan keputusan, informasi dunia kerja, dan pengetahuan tentang kelompok kerja yang disukai. Salami (2008) menyatakan bahwa kapasitas jati diri secara substansial berpengaruh terhadap career maturity seseorang. Bukti temuan ini menyebutkan bahwa seseorang yang mendapatkan kualitas jati dirinya perlu melewati fase pendalaman dan mempunyai tanggung jawab yang nyata terhadap pekerjaannya, dimana seseorang masih melacak jati dirinya. Dengan demikian, seseorang masih memerlukan bimbingan, fatwa, dan arahan dari ayah, ibu, dan atau anggota keluarga, sehingga ia dapat memilih kariernya secara tepat.

Sementara menurut Moeljono, kiat sukses dalam mengembangkan karier ada delapan langkah yang harus dilakukan oleh seorang pegawai, antara lain: (1) memperkaya pengetahuan, (2) meningkatkan keterampilan, (3) tidak hanya IQ, tetapi EQ, (4) SQ (Spiritual Quotient), (5) Vision Value Courage/ keteguhan hati, keberanian (VVC) Plus, (6) etika, (7) hukum, dan (8) keseimbangan karier dan keluarga. Pentingnya pengetahuan yang berhubungan langsung dengan karier sebagai pegawai (pustakawan) yaitu pengetahuan yang berkaitan dengan pekerjaan sehari-hari sebagai pegawai yang profesional. Pengetahuan yang tidak langsung berkenaa dengan karier tetapi bermanfaat: (a) bagi lembaga dimana pegawai bekerja, misalnya politik, kebijakan pemerintah, dan perkembangan informasi terkini, (b) bagi pekerjaan Anda, misalnya budaya lokal, bahasa asing, komputer, dan seterusnya, (c) bagi kualitas kemanusiaan Anda, misalnya HAM, gender, dan seterusnya.

Eliot (2007) dalam Simpson (2016), menyatakan sebagai organisme yang berkembang di lingkungan pendidikan tinggi, slogan "Library is the heart of the university" yang berarti perpustakaan adalah jantungnya perguruan tinggi sudah tidak asing di telinga pembaca. Akan tetapi sejauh mana jantung tersebut selalu dipelihara secara berkesinambungan sering pula terdengar menjadi pertanyaan, terutama oleh pustakawan yang memiliki tugas utama dalam memelihara bagian penting dalam lembaga informasi yang bernama perpustakaan. Pustakawan dengan kemampuan dan profesionalismenya mempunyai tugas yang sangat vital dalam menumbuhkembangkan perpusdokinfo, sehingga kemampuan dan profesionalisme pustakawan perlu terus dibina.

Sudarsono (2010) menjelaskan bahwa CPD dapat diterjemahkan sebagai Pengembangan Profesional Berkelanjutan (PPB) atau Pengembangan Keprofesionalan Berkelanjutan (PKB). Istilah pengembangan profesi dalam jabatan fungsional pustakawan memang telah lama dikenal dengan devinisi: "Kegiatan pustakawan dalam rangka pengamalan ilmu pengetahuan dan teknologi serta ketrampilan untuk meningkatkan mutu dan profesionalisme bidang kepustakawanan maupun dalam rangka menghasilkan sesuatu yang bermanfaat bagi peningkatan mutu layanan perpustakaan". Selanjutnya pembinaan karier tersebut diuraikan pada berbagai event terdiri atas: "menulis artikel ilmiah, bertugas sebagai ketua komunitas pustakawan, menyusun makalah pertemuan ilmiah, melakukan konsultasi konsep, membuat buku pedoman dan melakukan terjemahan dan membuat saduran". Dari definisi di atas dapat ditarik definisi CPD dalam konteks perpustakaan atau informasi adalah proses dimana kompetensi profesional perpustakaan dan spesialis informasi dipertahankan oleh pelaku perpustakaan (pustakawan) di sepanjang karier mereka. Adapun pengertian selengkapnya dari CPD adalah: "Suatu proses panjang dalam meningkatkan kemampuan, memperbarui keterampilan serta kompetensi seorang staf, yang dilakukan 
secara teratur dalam layanan pelatihan dan pendidikan, yang didukung oleh program eksternal", hal ini sesuai yang diungkapan oleh Prytherch (2005) dalam (Sudarsono, 2010). Dalam konteks profesional yang lebih umum CPD dapat diartikan sebagai: Pemeliharaan berkesinambungan dengan meningkatkan kemampuan dan pengetahuan, skill, keterampilan serta pengembangan kompetensi diri bagi pegawai dalam melaksanakan tugas teknis profesional selama perjalanan kariernya.

Dari definisi di atas dapat dipahami bahwa, apabila dibandingkan dengan definisi CPD yang biasa dipedomani oleh pihak-pihak kompeten dunia, maka ketetapan profesi pada jabatan fungsional pustakawan ternyata sangat sempit. Informasi mengenai implementasi konsep CPD dalam pembinaan profesi pustakawan belum banyak memperoleh perhatian. Hingga sekarang informasi yang berhubungan dengan implementasi konsep CPD dalam pengembangan profesi pustakawan masih sedikit dan kurang. Oleh sebab itu perlu dilakukan suatu kajian, tulisan ataupun penelitian tentang implementasi konsep CPD dalam pembinaan profesionalisme pustakawan Indonesia, khususnya pustakawan perpustakaan universitas/ sekolah tinggi/akademik. Secara garis besar CPD adalah tindakan memaksimalkan kemampuan sebagai individu yang kompeten, sebab dengan CPD pustakawan bisa: (1) mempertahankan dan membina kapabilitas dalam kinerja, (2) mampu bersaing dan berkompetisi di pasaran kerja, (3) memiliki tanggung jawab personal terhadap profesi dimasa mendatang, dan (4) melepaskan diri dari rasa bosan dan mengantisipasi adanya berbagai hal yang mungkin berubah dengan mengetengahkan tantangan akademis yang baru dan menyemangatkan (Sudarsono, 2010).

Merujuk dari uraian berbagai teori di atas, maka dapat disimpulkan bahwa dimensi dan indikator kematangan karier meliputi: membangun skill terhadap pengembangan sistem perpustakaan, mempelajari potensi diri sendiri pada minat, kemampuan, dan nilai-nilai yang dimiliki tentang karier, kepribadian individu, peran kehidupan, pendidikan berkelanjutan, terjaminnya akses pengembangan karier yang berkelanjutan, tahapan pertumbuhan karier, pengelolaan perpustakaan, pelayanan perpustakaan, pengembangan sistem kepustakawanan, pengembangan profesi dan kegiatan penunjang.

\section{METODE PENELITIAN}

Penelitian dilakukan di lingkungan Universitas Islam Negeri (UIN) Sunan Kalijaga Yogyakarta, Universitas Islam Indonesia (UII) Yogyakarta, Universitas Muhammadiyah Yogyakarta (UMY), Universitas Ahmad Dahlan (UAD) Yogyakarta, Universitas 'Aisyiyah (UNISA) Yogyakarta dan Universitas Nahdlatul 'Ulama (UNU) Yogyakarta. Waktu Penelitian derencanakan selama 4 (empat) bulan, antara bulan Desember 2017 sampai dengan Maret 2018. Populasi dalam hal ini adalah pustakawan yang ada di lingkungan 6 PTKI DIY. Penulis melibatkan semua populasi sejumlah 82 pustaka menjadi responden penelitian, sehingga penetapan sampel dengan model sensus (total sampling).

Pengumpulan data dengan menggunakan angket, diberikan langsung kepada responden berupa kuesioner tertutup, artinya setiap pertanyaan yang ada sudah tersedia jawaban yang harus dipilih oleh responden. Dalam hal ini responden diminta menjawab satu pertanyaan/pernyataan yang sesuai dengan keadaan yang dirasakan/dialaminya. angket tersebut berisi tentang butir-butir pernyataan dari variabel-variabel penelitian, yang terlampir dalam usulan penelitian ini. Kecuali melalui angket, pengumpulan data melalui wawancara terstruktur kepada perwakilan pustakawan di masing-masng PTKI (UIN Sunan Kalijaga, UII Yogyakarta, UMY, UAD 
Yogyakarta, UNISA Yogyakarta, dan UNUYogyakarta) untuk konfirmasi, jika terdapat ketidaksesuaian dengan petunjuk pengisian, jawaban ganda, atau responden tidak menjawab pada suatu pernyataan yang diajukan. Wawancara juga dimaksudkan untuk memperoleh informasi tentang faktor-faktor yang mempengaruhi kematangan karier pustakawan sebagai upaya penemuan teori baru. Kecuali data primer, pengumpulan data juga bersumber dari data sekunder dimana data diperoleh dari sumber kedua atau sumber sekunder. Pada studi ini data sekunder diperoleh dari Data Base Online Pustakawan Perpustakaan Nasional Rl, yaitu data yang diperoleh dengan cara membaca dan mengumpulkan berbagai bahan infromasi untuk mendukung penelitian ini melalui laman http:// pustakawan.perpusnas.go.id/pub/pustakawan.

Tabel 1 Jumlah Populasi Pustakawan

Perguruan Tinggi Islam di DIY

\begin{tabular}{|c|c|c|c|}
\hline No & Nama Perpustakaan & $\begin{array}{c}\text { Jumlah } \\
\text { Pustakawan }\end{array}$ & $\begin{array}{c}\text { Persentase } \\
(\%)\end{array}$ \\
\hline 1 & $\begin{array}{l}\text { Universitas Islam } \\
\text { Negeri (UIN) Sunan } \\
\text { Kalijaga Yogyakarta }\end{array}$ & 19 & 27.63 \\
\hline 2 & $\begin{array}{l}\text { Universitas Islam } \\
\text { Indonesia (UII) } \\
\text { Yogyakarta }\end{array}$ & 26 & 35.53 \\
\hline 3 & $\begin{array}{l}\text { Universitas } \\
\text { Muhammadiyah } \\
\text { Yogyakarta (UMY) }\end{array}$ & 15 & 19.74 \\
\hline 4 & $\begin{array}{l}\text { Universitas Ahmad } \\
\text { Dahlan (UAD) } \\
\text { Yogyakarta }\end{array}$ & 16 & 6.58 \\
\hline 5 & $\begin{array}{l}\text { Universitas 'Aisyiyah } \\
\text { (UNISA) Yogyakarta }\end{array}$ & 5 & 6.58 \\
\hline 6 & $\begin{array}{l}\text { Universitas Nahdlatul } \\
\text { ‘Ulama (UNU) } \\
\text { Yogyakarta }\end{array}$ & 1 & 3.95 \\
\hline & Jumlah & 82 & 100 \\
\hline
\end{tabular}

Sumber: Informan PTKI DIY
Analisis data dengan menggunakan statistik untuk menyederhanakan data penelitian dengan mencari data terendah dan data tertinggi, kemudia dicari rentangnya, maka lebar dan jumlah interval yang tepat dapat ditetapkan. Uji statistik dilakukan dengan menggunakan Analisis Deskriptip dan Analisis Regresi berganda. Pada penelitian ini peneliti melibatkan satu variabel bebas (eksogen) yakni religiusitas dan 1 variabel terikat (endogen) yaitu kematangan karier. Analisis data dilakukan dalam rangka membuktikan hipotesis penelitian, yang dirumuskan bahwa, Religiusitas $(X)$ berpengaruh terhadap kematangan karier $(\mathrm{Y})$. Analisis data dilakukan dalam rangka membuktikan hipotesis penelitian, yang dirumuskan bahwa, Religiusitas (X) berpengaruh terhadap kematangan karier $(\mathrm{Y})$.

\section{HASIL DAN PEMBAHASAN}

\section{Responden Penelitian}

Dalam penelitian ini PTKI di Daerah Istimewa Yogyakarta yang berbentuk universitas ditetapkan sebagai tempat penelitian. Dalam rangka mengumpulkan data primer dari pustakawan perguruan tinggi tersebut, studi dilakukan dengan angket yang dimintakan untuk diisi atau dijawab oleh pustakawan yang bersangkutan menyangkut angket tentang kepemimpinan profetik, budaya organisasi, religiusitas, kompetensi, dan kematangan karier. Dalam rangka memberikan ukuran yang lebih objektif, maka pustakawan yang secara definitif telah ditetapkan oleh lembaga induk responden yang bersangkutan terdiri dari pustakawan berijazah SLTA yang telah disetarakan melalui inpassing dan berpendidikan diploma (D2 atau 3), sarjana (S1), magister (S2), dan atau doktor (S3) ilmu perpustakaan.

Semua pustakawan di PTKI DIY tersebut berjumlah 82 pustakawan ditetapkan sebagai responden penelitian. Secara keseluruhan dari pengumpulan data diperoleh hasil bahwa seluruh 
angket kembali, setelah dilakukan evaluasi dan dikoreksi terbukti sebanyak 78 angket (95,12\%) kembali dengan isian lengkap, dan 4 angket $(4,88 \%)$ kembali tidak diisi (1 responden cuti umrah, 1 orang cuti melahirkan, dan 2 responden tanpa keterangan).

\section{Deskripsi Persepsi Responden terhadap Variabel Penelitian}

Variabel studi ini terdiri dari 2 variabel yaitu religiusitas $(\mathrm{X})$ dan kematangan karier $(\mathrm{Y})$. Kedua variabel tersebut terdiri dari 1 variabel bebas (eksogen) yakni $X$ dan 1 variabel terikat (endogen) yaitu Y. Masing-masing variabel mempunyai indikator antara lain: $\mathrm{X}$ terdiri dari 5 indikator, dan $\mathrm{Y}$ terdiri dari 7 indikator, sehingga secara keseluruhan terdiri dari 12 indikator.

Hasil studi yang ditulis pada sub bab ini mencoba mendeskripsi mengenai persepsi responden atas variabel-variabel dan indikator-indikator dengan menjawab angket yang diajukan oleh peneliti. Pengukuran persepsi atas indikator variabel dengan skala Likert dimana skor nilai jawaban 1 sampai 5, maka pengolahan data deskripsi jawaban responden disusun sebagaimana diuraikan dibawah ini.

Sementara pada studi ini dibuat rumusan terhadap kategori tingkatan tinggi rendahnya indikator dan atau variabel dijabarkan sebagaimana disajikan dalam uraian berikut ini:

Tabel 2 Kategori Tingkatan Tinggi/

Rendahnya Indikator atau Variabe

\begin{tabular}{|cc|}
\hline Nilai / Skor & Kategori \\
\hline $0-19$ & Sangat Jelek \\
\hline $20-39$ & Jelek \\
\hline $40-59$ & Sedang \\
\hline $60-79$ & Baik \\
\hline $80-100$ & Sangat Baik \\
\hline
\end{tabular}

Sumber: Sungadi (2018)

\section{Persepsi Responden terhadap Variabel Religiusitas (X)}

Variabel religiusitas memiliki 5 parameter, antara lain: ideologi/akidah, praktik ritual ibadah, pengalaman/akhlakul karimah, konsekuensi yang mempengaruhi perilakunya/ihsan, dan pengetahuan agama/ilmu. Kuisioner yang diberikan kepada informan dalam variabel religiusitas sebanayak 45 nomor pernyataan, setelah diuji validitas terdapat 8 nomor pernyataan tidak valid (nomor 12, 13, 15, 16, 17, 18, 30, dan 40), sehingga hanya 37 nomor yang dapat dipakai untuk diuji statistik.

Dalam Tabel 4 terlihat bahwa kekuatan pada setiap dimensi dan variabel religiusitas pada tataran klaifikasi sangat baik. Dari 5 dimensi yang mempunyau klasifikai terbaik adalah dimensi akidah/ideologi mempunyai nilai 89.9, diikuti masing-masing dimensi pengalaman beragama/ akhlakul karimah sebesar 86.5, indikator pengetahuan ilmu beragama 86.3, praktik ritual ibadah 84.9, dan sifat ihsan dengan angka senilai 84,4. Selanjutnya klasifikasi variabel religiusitas oleh informan dinilai dalam klasifikasi sangat tinggi dengan nilai 86,67 .

Tabel 3 Tingkat Persepsi Responden terhadap Variabel Religiusitas

\begin{tabular}{|c|c|c|c|c|c|}
\hline Variabel & Dimensi & $\begin{array}{c}\text { Skor } \\
\text { Jawaban }\end{array}$ & $\begin{array}{c}\text { Skor } \\
\text { Kumulatif }\end{array}$ & Rerata & Kategori \\
\hline \multirow[t]{5}{*}{ Religiusitas } & & 12507 & 14430 & 86,67 & $\begin{array}{c}\text { Sangat } \\
\text { Baik }\end{array}$ \\
\hline & $\begin{array}{l}\text { Ideologi/ } \\
\text { Akidah }\end{array}$ & 3507 & 3900 & 89.9 & $\begin{array}{c}\text { Sangat } \\
\text { Baik }\end{array}$ \\
\hline & $\begin{array}{l}\text { Praktik Ritual } \\
\text { Ibadah }\end{array}$ & 1656 & 1950 & 84.9 & $\begin{array}{c}\text { Sangat } \\
\text { Baik }\end{array}$ \\
\hline & $\begin{array}{l}\text { Pengalaman/ } \\
\text { Akhlakul } \\
\text { Karimah }\end{array}$ & 2700 & 3120 & 86.5 & $\begin{array}{l}\text { Sangat } \\
\text { Baik }\end{array}$ \\
\hline & $\begin{array}{l}\text { Konsekuensi } \\
\text { yang } \\
\text { Mempengaruhi } \\
\text { Perilakunya/ } \\
\text { Ihsan }\end{array}$ & 2962 & 3510 & 84.4 & $\begin{array}{c}\text { Sangat } \\
\text { Baik }\end{array}$ \\
\hline & $\begin{array}{l}\text { Pengetahuan } \\
\text { Agama/IImu }\end{array}$ & 1682 & 1950 & 86.3 & $\begin{array}{c}\text { Sangat } \\
\text { Baik }\end{array}$ \\
\hline
\end{tabular}

Sumber: data primer diolah $\mathrm{N}=78,2018$ 
Dari hasil olah data tampak bahwa tingkatan di seluruh indikator dan variabel religiusitas dalam tingkatan kategori sangat tinggi. Dari 5 indikator terdiri dari indikator akidah/ideologi dengan skor 89.9, disusul berturut-turut indikator pengalaman beragama/akhlakul karimah sebesar 86.5, indikator pengetahuan ilmu beragama 86.3, praktik ritual ibadah 84.9, dan sifat ihsan dengan angka senilai 84,4. Selanjutnya klasifiksi variabel religiusitas oleh informan dinilai dalam tingkatan klasifikasi sangat tinggi dengan nilai 86,67.

Dalam hal ini dapat dipahami bahwa, para pustakawan Perguruan Tinggi Islam di DIY telah memahami dan menjalankan ajaran Islam dengan baik dan benar. Ajaran Islam yang benar menurut AI Quran Surat Al Baqarah 177, (lihat lampiran terjemah Quran nomor 16).

Pada QS 2:177 tersebut mengandung beberapa aspek ibadah mahdhah dan ghairu mahdhah yang meliputi nilai-nilai aqidah, kemanusiaan, 'ubudiyah, kesyukuran, harga diri (muru'ah), dan kepasrahan diri (tawakkal).

\section{Tanggapan Responden terhadap Variabel Kematangan Karier ( $Y$ )}

Variabel kematangan karier mempunyai 7 indikator, antara lain: potensi diri, implementasi karier secara kontinyu, memiliki kemampuan merumuskan program pengembangan perpustakaan dan karier, memiliki kemampuan meningkatkan prestasi kerja perpustakaan dan karier dengan penuh tanggung jawab dan professional, mampu melakukan kegiatan pengembangan profesi, memiliki akses karier secara lanjut, dan kegiatan penunjang pustakawan. Angket penelitian yang disampaikan kepada informan pada variabel religiusitas sebanyak 51 butir pernyataan setelah diuji validitas terdapat 1 nomor pernyataan tidak valid (nomor 1), dengan demikian ada 50 nomor pernyataan yang valid dipakai untuk uji statistik. Pada Tabel 4 disajikan persepsi responden terhadap varaiabel kematangan karier.

Tabel 4 Tingkat Persepsi Responden terhadap Variabel Kematangan Karier

\begin{tabular}{|c|c|c|c|c|c|}
\hline Variabel & Dimensi & $\begin{array}{c}\text { Skor } \\
\text { Jawaban }\end{array}$ & $\begin{array}{c}\text { Skor } \\
\text { Kumulatif }\end{array}$ & Rerata & Kategori \\
\hline \multirow[t]{8}{*}{$\begin{array}{l}\text { Kematangan } \\
\text { Karier }\end{array}$} & & 15179 & 19500 & 77,82 & Baik \\
\hline & Potensi Diri & 3775 & 5070 & 74.5 & Baik \\
\hline & $\begin{array}{l}\text { Mengimplementasikan } \\
\text { Karier secara Konsisten }\end{array}$ & 2511 & 3120 & 80.5 & $\begin{array}{c}\text { Sangat } \\
\text { Baik }\end{array}$ \\
\hline & $\begin{array}{l}\text { Mampu Membuat } \\
\text { Rencana } \\
\text { Pengembangan } \\
\text { Perpustakaan } \\
\text { dan Karier }\end{array}$ & 1495 & 1950 & 76.7 & Baik \\
\hline & $\begin{array}{l}\text { Mampu Meningkatkan } \\
\text { Kinerja Perpustakaan } \\
\text { dan Karier secara } \\
\text { Ilmiah dan Profesional }\end{array}$ & 3415 & 4290 & 79.6 & Baik \\
\hline & Kematangan Profesi & 822 & 1170 & 70.3 & Baik \\
\hline & $\begin{array}{l}\text { Akses Kematangan } \\
\text { Karier Berkelanjutan }\end{array}$ & 2257 & 2730 & 82.7 & $\begin{array}{c}\text { Sangat } \\
\text { Baik }\end{array}$ \\
\hline & $\begin{array}{l}\text { Penunjang Kegiatan } \\
\text { Kepustakawanan }\end{array}$ & 904 & 1170 & 77.3 & Baik \\
\hline
\end{tabular}

Sumber: data primer diolah $\mathrm{N}=78,2018$

Pada Tabel 4 terlihat bahwa variabel kematangan karier dalam klasifikasi baik dan persepsi pada setiap indikator dalam kondisi sangat baik sampai dengan baik. Akses kematangan karier berkelanjutan dan implementasi karier secara kontinyu pada klasifikasi sangat baik dengan nilai 82.7 dan 80,5 . Dari 5 parameter yang mempunyai klasifikasi baik dengan nilai paling tinggi adalah parameter mampu berprestasi terhadap pekerjaan perpustakaan dan berkarier secara ilmiah secara professional mendapatkan skor nilai 79.6, diikuti parameter penunjang kegiatan pustakawan senilai 77.3, parameter kemampuan menciptakan program kerja pengembangan perpustakaan dan karier senilai 76.7, parameter pengembangan potensi diri senilai 74.5, dan parameter pengembangan profesi dengan angka senilai 70,3. Selanjutnya klasifikasi 
variabel kematangan karier oleh responden dinilai pada klasifikasi baik bernilai 77,82 . Hasil olah data ini dapat dinyatakan bahwa karier pustakawan Pendidikan Tinggi Keagamaan Islam (PTKI) di DIY dalam kondisi baik yang mengarah pada pencapian kematangan karier.

\section{HASIL ANALISIS PENGUJIAN HIPOTESIS}

\section{Pengaruh Religiusitas terhadap Kematangan Karier}

Tabel 5 Pengaruh Religiusitas terhadap Kematangan Karier

\begin{tabular}{|l|c|c|c|}
\hline \multirow{4}{*}{ Religiusitas } & \multicolumn{3}{|c|}{ Correlations } \\
\hline & $\begin{array}{c}\text { Pearson } \\
\text { Correlation }\end{array}$ & 1 & $.292^{* *}$ \\
\cline { 2 - 4 } & Religiusitas & $\begin{array}{c}\text { Kematangan } \\
\text { Karier }\end{array}$ \\
\cline { 2 - 4 } & $\mathrm{N}$-tailed) & 78 & .009 \\
\hline \multirow{3}{*}{$\begin{array}{l}\text { Kematangan } \\
\text { Karier }\end{array}$} & $\begin{array}{c}\text { Pearson } \\
\text { Correlation }\end{array}$ & $.292^{* *}$ & 1 \\
\cline { 2 - 4 } & Sig. (2-tailed) & .009 & \\
\cline { 2 - 4 } & $\mathrm{N}$ & 78 & 78 \\
\hline
\end{tabular}

**. Correlation is significant at the 0.01 level (2-tailed).

Dampak religiusitas $(\mathrm{X})$ terhadap kematangan karier $(\mathrm{Y})$ dinyatakan bahwa pustakawan menilai PTKI di DIY terhadap religiusitas (X) memiliki pengaruh substansional kepada kematangan karier (Y) dengan angka substansional $(0,009<0,05)$. Hasil uji melalui analisa data secara bersama-sama buktinya dapat dilihat dalam Tabel 5 dan dapat dinyatakan bahwa dampak langsung tanggapan pustakawan pada PTKI di DIY antara variabel religiusitas $(\mathrm{X})$ terhadap variabel kematangan karier $(\mathrm{Y})$ sebesar 0,292 dengan nilai signifikansi sebesar 0,005 . Hasil ini terbukti bahwa terdapat dampak positif dan signifikan antara religiusitas (X) pada kematangan karier (Y). Bukti ini berarti bahwa religiusitas yang dinilai oleh pustakawan sebagai gejala yang positif (baik, tinggi), maka tanggapan pustakawan kepada kematangan karier akan baik (tinggi) pula.
Dukungan dari hasil riset ini diperoleh dari periset Turki bernama Meral Elçia, Erge Sener, dan Lütfihak Alpkan (2011) dimana riset mereka meneliti hubungan antara moralitas dan religiusitas dengan perilaku pekerja keras. Hasil penelitiannya menunjukkan bahwa baik moralitas maupun religiusitas karyawan berpengaruh positif terhadap perilaku pekerja keras mereka. Temuan penelitian ini juga menunjukkan bahwa religiusitas adalah faktor yang berarti gender pria secara substansial lebih tinggi daripada wanita dalam kehidupan bisnis; Sementara pria memiliki tingkat pekerja keras yang jauh lebih tinggi bila dibandingkan dengan wanita. Temuan penting lainnya adalah bahwa orang yang sudah menikah memiliki tingkat moralitas dan pekerja keras yang jauh lebih tinggi bila dibandingkan dengan orang lajang. Namun, hubungan antara status perkawinan dan religiusitas tidak dapat ditemukan. Akhirnya, lulusan master/ doktor dan universitas memiliki jumlah religiusitas yang jauh lebih rendah dari yang lainnya. Lulusan magister / doktor memiliki jumlah pekerja keras yang jauh berbeda dengan lulusan sekolah dasar / menengah.

Hubungan antara etika kerja dengan religiusitas sebelumnya dipelajari dalam literatur, namun penelitian ini dilakukan di negara-negara di mana agama Kristen adalah agama yang dominan. Studi ini dilakukan di Turki, di mana agama Islam tersebar luas, ini adalah salah satu kontribusi studi ini (99,8\% populasi Turki adalah mayoritas Muslim).

Kontribusi lain dari penelitian ini terkait dengan metodologinya. Hasil kajian literatur menunjukkan bahwa pengukuran etos kerja pada sebagian besar penelitian didasarkan pada "satu dimensi". Etika kerja diukur sebagai konstruksi multidimensional hanya dalam beberapa studi. Penelitian ini merupakan salah satu penelitian yang mengukur etos kerja dengan dua dimensi. Namun kontribusi ini juga merupakan batasan studi, yang 
merupakan penggunaan hanya dua dari tujuh dimensi The Protestant Work Ethic (PWE). Caranya masih terbuka bagi peneliti untuk meneliti lima dimensi PWE lainnya yaitu: kemandirian, waktu senggang, sentralitas kerja, waktu terbuang, dan keterlambatan gratifikasi.

Selain itu, dari hasil regresi terbukti bahwa moralitas dan religiusitas merupakan pendahulunya dari pekerja keras. Hubungan terbalik mungkin ada, dan ini harus diselidiki dalam penelitian selanjutnya juga. Sedangkan untuk implikasi penelitian lebih lanjut, temuan dan keterbatasan ini dapat membuka jalan baru untuk penelitian selanjutnya mengenai penyelidikan semua dimensi PWE pada sampel responden yang lebih besar yang memiliki gelar profesional dan bahkan agama yang berbeda. Terlepas dari keterbatasan yang disebutkan di atas, adalah sepengetahuan kita bahwa ada beberapa studi yang membahas hubungan-hubungan ini di Turki.

Penelitian selanjutnya dianjurkan untuk mengembangkan literatur dengan mempertimbangkan keterbatasan tersebut. Pengaturan penelitian baru dan yang lebih maju mungkin dirancang. Misalnya, dalam penelitian lebih lanjut, unit analisis mungkin merupakan organisasi daripada individu dan sampelnya mungkin diperbesar ke sektor bisnis lain. Hal ini juga memungkinkan untuk memperluas model teoritis dengan memasukkan tambahan (1) variabel dependen seperti kecerdasan emosional, kinerja kerja, stres dan beberapa perilaku terkait pekerjaan seperti: kematangan karier, kepuasan kerja, komitmen organisasi dan niat berpindah dan (2) variabel kontrol, moderasi atau memediasi variabel seperti usia, jenis kelamin atau kepribadian.

Perilaku pekerja keras, salah satu dimensi etik kerja yang signifikan, adalah perilaku perilaku karyawan yang paling diantisipasi di semua organisasi. Namun, penelitian tentang hubungan kerja keras dengan variabel lainnya terbatas. Temuan penelitian ini menunjukkan bahwa moralitas dan Religiusitas adalah faktor yang keduanya memiliki dampak positif terhadap perilaku pekerja keras. Selain itu, ditemukan bahwa pekerja keras, religiusitas dan moralitas berbeda menurut jenis kelamin, status perkawinan dan tingkat pendidikan peserta. Disarankan agar penelitian ini memberikan kontribusi terhadap literatur dengan temuannya mengenai hubungan moralitas, religiusitas dan perilaku pekerja keras.

Peneliti lain juga menguatkan hasil kajian ini, yang dilakukan oleh Amaliah, Aspiranti, dan Purnamasari (2015) yang menguraikan bahwa, menurut hasil pengujian hipotesis, hipotesis penelitian diterima dimana nilai religios berdampak positif secara substansional pada kepuasan kerja islami. Pemahaman yang baik tentang nilai-nilai agama membuat seorang karyawan mendapatkan kepuasan kerja baik secara material maupun spiritual. Perasaan syukur, sekaligus memahami makna kerja di industri membuat karya bordir yang terlihat khusus tidak hanya untuk mencari nafkah tapi juga sebagai wujud kewajibannya kepada Tuhan.

Penelitian yang sudah pernah dilakukan oleh beberapa peneliti sebelumnya mengenai kematangan karier Sumber Daya Manusia (SDM), termasuk di dalamnya karier pustakawan antara lain: Hasil riset yang dilakukan Hasan (2006) membuktikan bahwa konsepsi diri, semangat kerja, dan gender berpengaruh terhadap career maturity. Sementara riset yang dilakukan Ottu dan Idowu (2014) membuktikan bahwa sifat terbuka terhadap pengalaman (opennes to experience) berpengaruh terhadap career maturity. Bukti riset ini membuktikan bahwa penjajakan, pendalaman, dan pemilihan karier bagi seseorang masih perlu bimbingan, arahan, dan pertimbangan dari orangorang terdekat di sekelilingnya. Seseorang memer- 
lukan transparasi, kepedulian, dan dukungan secara utuh terhadap hasrat, kebolehan, talenta, dan keahlian untuk dapat membuktikan career maturity yang tinggi serta tanggung jawab pada profesi yang di pilih. Studi ini juga membuktikan bahwa kematangan karier dipengaruhi oleh gender, umur, dan kesukuan/kedaerahan. Powell dan Luzzo (1998) menyatakan dari hasil risetnya membuktikan bahwa faktor demografi yang berpengaruh terhadap career maturity siswa SMA adalah gender, kluster, dan jenis kelulusan, atau silabus. Sementara Bozgeyikli, Eroglu, dan Hamureu (2009) dari hasil risetnya membuktikan bahwa status sosial ekonomi secara substansial berpengaruh terhadap career maturity remaja di Turki. Lau, Low, dan Zakaria (2004) melakukan riset pada 76 pelajar baru di public university membuktikan bahwa perencanaan karier sebagai salah satu faktor yang berpengaruh terhadap perkembangan career maturity teruntuk bagi seluruh gender. Career maturity yang tinggi adalah dimana pelajar mempunyai kekayaan informasi yang memadai serta dapat merancang karier secara baik, sehingga mereka mampu memilih dan menentukan karier secara benar. Hasil riset Chatterjee (2013) membuktikan bahwa pada tahapan perkembangan karier, dimensi perancangan karier dapat berkontribusi penuh terhadap career maturity siswa. Perancangan karier merupakan keputusan tepat di awal pembinaan profesi serta proses untuk memutuskan memilih profesi. Ada teori yang berhubungan dengan karier mengakui bahwa untuk menetapkan suatu pilihan karier dan menentukan keputusan terhadap profesi yang dipilih, individu wajib mempunyai perancangan dan career maturity yang dibuktikan lewat pengkajian potensi diri yang dipunyai, pemahaman tentang informasi profesi yang berkaitan, dan bayangan terhdap karier. Berdasarkan uraian beberapa penelitian tersebut, maka beberapa faktor yang berpengaruh terhadap career maturity adalah kualitas jati diri, konsepsi diri, potensi diri, impian karier, transparasi terhadap pengalaman, perancangan profesi, gender, umur, kesukuan, kluster, dan jenis silabus. Mandayun (2015) yang menyelidiki kinerja pegawai pada UMS Surakarta terbukti bahwa religiositas mempunyai dampak positif dan substansial terhadap prestasi kerja pegawai UMS. Hasil riset membuktikan nilai $p$ value lebih kecil dari tingkat signifikansi $=5 \%$ atau $(0,000<0,05)$. Hasil ini membuktikan adanya dampak substansional variabel religiositas pada prestasi kerja pegawai. Hasil dari uji deskriptif membuktikan bahwa sebagian besar pegawai UMS menilai dengan persepsi sangat baik pada variabel religiositas. Dari uraian ini dapat dipahami bahwa dengan adanya praktik religiositas yang baik mampu meningkatkan prestasi kerja pegawai. Dengan adanya tingkat pemahaman agama atau religiositas pada pustaakwan dapat membentuk pribadi yang jujur, tanggung jawab, sikap santun dan tolong menolong, sehingga seseorang dapat selalu berpikiran positif dalam beraktivitas. Hasil penelitian lain yang dilakukan Fitriyaningsih (2012) juga membuktikan hasil yang sama yakni religiositas mempunyai dampak signifikan terhadap prestasi kerja karyawan di BMT Yogyakarta. Akan tetapi, dari pengujian individu terhadap ke 5 indikator religiositas yakni aqidah, praktik agama, pengamalan, pengetahuan dan pengalaman hanya satu indikator yang mempunyai dampak substansional, yakni indikator pengalaman. Dari hasil para peneliti di atas menunjukkan bahwa faktor kematangan beragama (religiusitas) ada pengaruh yang siginifikan terhadapat kinerja sesorang, dalam hal ini dapat dimaknai bahwa semakin tinggi pemahaman keagamaan seseorang maka akan mampu meningkatkan kinerja seorang pegawai. Hasil penelitian Sungadi (2016) menunjukkan bahwa Tingkat kepercayaan diri Pustakawan UII dalam menjalani profesi pustakawan berada pada posisi tinggi sebesar 
68\%. Tingkat pengembangan karier Pustakawan UII berada pada posisi tingkat sedang sebesar $50 \%$. Lebih lanjut dari peneltian sungadi tersebut diperoleh hasil bahwa tingkat korelasi antara kepercayaan diri dengan pengembangan profesi pustakawan UII adalah sebesar $30 \%(0,300)$. Artinya pengaruh pengembangan karier pustakawan dari kepercayaan diri hanya sebesar $30 \%$ saja, sementara masih ada faktor diluar kepercayaan diri sebesar $70 \%$ yang mempengaruhi pengembangan karier pustakawan. Faktor lain di luar kepercayaan diri tersebut antara lain: (1) adanya tugas ganda bagi pustakawan sehingga pekerjaan kepustakawanan hampir tidak tersentuh; (2) adanya program pelatihan dan peningkatan pendidikan yang lebih tinggi bagi pustakawan di bidang kepustakawanan; (3) adanya motivasi yang tinggi bagi pustakawan juga dapat mempengaruhi peningkatan profesi pustakawan; (4) lingkungan kerja yang kondusif; dan (5) adanya kepemimpinan profetik yang diberlakukan di lembaga dimana pustakawan mengembangkan profesinya. Seseorang yang mampu mengatur dirinya secara baik akan memiliki tanggug jawab terhadap perjalanan kariernya. Selaras dengan hasil penelitian Sungadi (2011) bahwa adanya jiwa kepemimpinan yang profetik berkorelasi positif terhadap produktivitas kerja pustakawan dengan kontribusi pengaruhnya sebesar $73,7 \%$. Semakin tinggi nilai jiwa kepemimpinan, maka semakin tinggi pula produktivitas kerja bagi pustakawan. Dalam hal ini dapat merujuk pada Al Quran Alam Nasyrah: 7. (lihat lampiran terjemah Quran nomor 14). Maksud dari ayat ini adalah bahwa pustakawan harus selalu berkarya dan berkarya serta tidak boleh menunda-nunda suatu perkerjaan, sehingga kematangan karier sebagai pustakawan akan lebih mudah dicapai.

Faktor lain yang diduga berpengaruh terhadap peningkatan kinerja adalah kompetensi pustakawan. Kompetensi merupakan segala aspek yang dipunyai oleh pustakawan berupa, knowledge, skill, dan sikap yang baik yang mendukung dan membantu pelaksanaan tugas atau pekerjaanya di perpustakaan. Kompetensi dapat dibentuk antara lain melalui pendidikan dan pelatihan agar dapat melaksanakan tugasnya sesuai standar yang diinginkan. Dengan kompetensi yang dimiliki oleh setiap pustakwan diharapkan tugas kepustakawanan dapat berjalan dengan baik. Dengan demikian semakin tinggi kompetensi pustakawan maka akan semakin meningkat pula kinerja pustakawan terhadap perpustakaan.

\section{Hasil Pengujian dan Analisis antar Indikator terhadap Variabel}

Pengujian antar indikator terhadap variabel ini digunakan untuk mengetahui kekuatan indikator terhadap masing-masing variabel, sehingga dari hasil pengujian ini akan dapat dibuktikan parameter mana yang sangat berpengaruh terhadap variabel yang bersangkutan. Dari hasil perhitungan itu, indikator yang paling kuat dukungannya terhadap variabel akan dikaji lebih mendalam dalam rangka untuk menemukan teori baru.

\section{Indikator Variabel Religiusitas (X)}

Variabel religiusitas (X) memiliki 5 indikator: ideologi/akidah $(97,90 \%)$, praktik ritual ibadah (75,27\%), pengalaman/akhlakul karimah (69,30\%;), konsekuensi yang mempengaruhi perilakunya/ ihsan (85,67\%), dan pengetahuan agama/ilmu $(84,28 \%)$. Kekuatan terbesar terletak pada indikator ideologi/akidah $(97,90 \%)$ dan terkecil pada aspek perilaku/ihsan (69,30). Selanjutnya parameter ideologi/akidah terdiri dari 10 nomor pertanyaan, setelah diuji terbukti bahwa, dari parameter ideologi/akidah mempunyai 5 pengaruh terbesar yang meliputi: seorang pustakawan didalam menjalankan profesi perlu memiliki keyakinan bahwa Allah SWT akan selalu menolong hambaNya, 
(99,33\%), memegang teguh ajaran Islam (78,44\%), dibalik kesulitan pasti ada kemudahan (86,87\%), Allah SWT memberikan ujian sesuai dengan batas kemampuan (77,86\%), dan Agama Islam mengatur seluruh aspek kehidupan (74,16\%).

Tabel 6 Kekuatan Indikator X terhadap Variabel Religiusitas (X)

\begin{tabular}{|l|c|c|c|c|c|c|}
\hline \multirow{2}{*}{$\begin{array}{l}\text { Skor } \\
\text { Indikator }\end{array}$} & \multicolumn{6}{|c|}{ Test Value $=0$} \\
\cline { 2 - 7 } $\begin{array}{l}\text { Variabel } \\
\text { Religiusitas }\end{array}$ & $\mathrm{t}$ & $\mathrm{df}$ & $\begin{array}{c}\text { Sig. } \\
\text { (2-tailed) }\end{array}$ & $\begin{array}{c}\text { Mean } \\
\text { Difference }\end{array}$ & \multicolumn{2}{c|}{$\begin{array}{c}\text { 95\% Confidence } \\
\text { Interval of the } \\
\text { Difference }\end{array}$} \\
\cline { 5 - 8 } & & & Lower & Upper \\
\hline $\begin{array}{l}\text { Ideologi/ } \\
\text { Akidah }\end{array}$ & 97.90 & 77 & .000 & 44.962 & 44.05 & 45.88 \\
\hline $\begin{array}{l}\text { Paktik Ritual } \\
\text { Ibadah }\end{array}$ & 75.27 & 77 & .000 & 21.231 & 20.67 & 21.79 \\
\hline Pengalaman & 69.30 & 77 & .000 & 34.615 & 33.62 & 35.61 \\
\hline Ihsan & 85.67 & 77 & .000 & 37.974 & 37.09 & 38.86 \\
\hline $\begin{array}{l}\text { Pengetahuan } \\
\text { Agama/Imu }\end{array}$ & 84.28 & 77 & .000 & 21.564 & 21.05 & 22.07 \\
\hline
\end{tabular}

Sumber: data primer diolah $\mathrm{N}=78,2018$

Hasil kajian ini memberikan bukti bahwa parameter kematangan karier pustakawan PTKI di DIY memperoleh kekuatan dari aspek aqidah yang kuat, artinya bahwa bagi pustakawan dalam melaksanakan tugasnya perlu memiliki keyakinan bahwa Allah SWT akan selalu menolong hambaNya, memegang teguh ajaran Islam, dibalik kesulitan pasti ada kemudahan, Allah SWT memberikan ujian sesuai dengan batas kemampuan, dan Agama Islam mengatur seluruh aspek kehidupan.

\section{Indikator Variabel Kematangan Karier ( $\mathrm{Y}$ )}

Variabel kematangan karier (Y) memiliki 7 indikator: mempelajari potensi diri $(83,07 \%)$, mengimplementasikan karier secara konsisten (82,63\%), membuat perencanaan pengembangan perpustakaan dan karier $(67,05 \%)$, pengembangan sistem kepustakawanan (85,27\%), Kematangan profesi $(41,28 \%)$, akses kematangan karier berkelanjutan $(94,20 \%)$, dan penunjang kegiatan kepustakawanan (52,39\%). Kekuatan terbesar terletak pada indikator akses kematangan karier berkelanjutan $(94,20 \%)$ dan terkecil pada aspek pengembangan profesi $(41,28 \%)$.

Tabel 7 Kekuatan Indikator Y terhadap

Variabel Kematangan Karier (Y)

\begin{tabular}{|c|c|c|c|c|c|c|}
\hline \multirow{3}{*}{$\begin{array}{l}\text { Skor Indikator } \\
\text { Variabel } \\
\text { Kematangan } \\
\text { Karier }\end{array}$} & \multicolumn{6}{|c|}{ Test Value $=0$} \\
\hline & \multirow[t]{2}{*}{$\mathrm{t}$} & \multirow[t]{2}{*}{ df } & \multirow[t]{2}{*}{$\begin{array}{c}\text { Sig. } \\
\text { (2-tailed) }\end{array}$} & \multirow[t]{2}{*}{$\begin{array}{c}\text { Mean } \\
\text { Difference }\end{array}$} & \multicolumn{2}{|c|}{$\begin{array}{l}95 \% \text { Confidence } \\
\text { Interval of the } \\
\text { Difference }\end{array}$} \\
\hline & & & & & Lower & Upper \\
\hline Y1 Potensi Diri & 83.07 & 77 & .000 & 48.397 & 47.24 & 49.56 \\
\hline Y2 Konsisten & 83.62 & 77 & .000 & 32.192 & 31.43 & 32.96 \\
\hline $\begin{array}{l}\text { Y3 Mampu } \\
\text { Buat Rencana }\end{array}$ & 67.05 & 77 & .000 & 19.167 & 18.60 & 19.74 \\
\hline $\begin{array}{l}\text { Y4 Pengemb } \\
\text { Sistem }\end{array}$ & 85.27 & 77 & .000 & 43.782 & 42.76 & 44.80 \\
\hline $\begin{array}{l}\text { Y5 } \\
\text { Pengembangan } \\
\text { Profesi }\end{array}$ & 41.28 & 77 & .000 & 10.538 & 10.03 & 11.05 \\
\hline $\begin{array}{l}\text { Y6 Akses Karier } \\
\text { Berkelanjutan }\end{array}$ & 94.20 & 77 & .000 & 28.936 & 28.32 & 29.55 \\
\hline $\begin{array}{l}\text { Y7 Kegiatan } \\
\text { Penunjang }\end{array}$ & 52.39 & 77 & .000 & 11.538 & 11.10 & 11.98 \\
\hline
\end{tabular}

Sumber: data primer diolah $\mathrm{N}=78,2018$

Parameter akses karier berkelanjutan di atas meliputi dari 7 nomor pertanyaan, setelah diuji mendapatkan hasil, bahwa bagi pustakawan pada saat menjalankan profesi perlu adanya dukungan yang berupa akses karier berkelanjutan yang mempunyai 5 pengaruh terbesar diantaranya: mendapat dukungan positif dari kawan non pustakawan (80,15\%), meyakini prospek baik terhadap profesi pustakawan $(76,73 \%)$, mempunyai harapan peran strategis terhadap asosiasi profesi pustakawan $(66,14 \%)$, mendapat dukungan penuh dari keluarga $(77,61 \%)$, dan mendapat dukungan penuh dari sesama pustakawan di kantornya (82,31\%).

Dari hasil kajian ini dapat dipahami bahwa parameter kematangan karier pustakawan PTKI di DIY dipengaruhi oleh aspek akses karier berkelanjutan yang tinggi, artinya bahwa pustakawan dalam melaksanakan tugasnya memerlukan dukungan positif dari kawan non pustakawan, meyakini bahwa profesi pustakawan mempunyai prospek baik di masa depan, mempunyai harapan peran strategis terhadap asosiasi profesi pustakawan, mendapat 
dukungan penuh dari keluarga, dan mendapat dukungan penuh dari sesama pustakawan di kantornya.

\section{Pembuktian Hipotesis}

Berdasarkan hasil pengujian hipotesis sebagaimana tersaji pada Tabel III.5 dan dari hasil analisis regresi maka, dalam penelitian ini dapat dijelaskan hipotesis sebagai berikut: Religiusitas (X) berpengaruh signifikan terhadap kematangan karier (Y) terdapat nilai pengaruh sebesar 0,292 dengan substansial 0,009 $<0,05$. Artinya menerima hipotesis yang menyebutkan bahwa religiusitas berdampak pada kematangan karier.

\section{Temuan Teoritis dan Aplikatif}

Hasil kajian teoritik dari disertasi ini pada hakekatnya merupakan penguatan kembali terkait adanya perbedaan dengan penelitian terdahulu dan sekaligus hasil analisis yang tidak sesuai dengan rumusan hipotesis yang dirumuskan berdasarkan asumsi beberapa teori. Beberapa hasil analisis yang berkaitan dengan teori baru dalam disertasi ini meliputi:

a. Temuan teoritis yang diajukan dalam penelitian ini mengambil Teori Imbal Balik yang digagas oleh Super (1990), dimana pada teori Super ini menjelaskan bahwa dimensi kematangan karier terdiri dari dimensi internal (biografis) dan dimensi geografis (eksternal). Dimensi biografis merupakan bentuk dari komponen kepribadian individu yang antara lain meliputi 6 indikator terdiri dari:kecerdasan, bakat, dan bakat khusus, kebutuhan, nilai-nilai, dan kepentingan. Sementara dimensi geograis (eksternal) yang mempengaruhi peran kehidupan seseorang, mempunyai 7 indikator antara lain: ekonomi, masyarakat, pasar tenaga kerja, komunitas, keluarga, sekolah, dan kelompok kerja. Dengan demikian dimensi kematangan karier menurut Teori Super secara keseluruhan terdiri dari 13 indikator. Berlan- daskan teori tersebut Penelitian ini mengajukan konsep dimensi kematangan karier dari 13 indikator mengambil 1 indikator, yaitu indikator religiusitas dan kompetensi mewakili dimensi biografis (internal). Atas dasar hasil analisis data dapat diketahui bahwa dari hasil uji hipotesis menunjukkan terjadi pengaruh antara religiusitas terhadap kematangan karier.

Akan tetapi hasil telaah dari berbagai referensi dan informasi dari para pakar di bidang kepustakawanan belum ditemukan faktor-faktor yang mempengaruhi kematangan karier pustakawan. Kajian tentang variabel yang berpengaruh terhadap kinerja, produktivitas kerja, kepuasan kerja telah banyak dikaji oleh peneliti terdahulu antara lain: Batubara (2017), Priastuti (2015), Elsintania (2016), Baoguo Xie dkk. (2016), Guan (2016), Russell (2016), Widiasih (2017), Alawiyah (2014), Yahya dkk (2015), Chasanah (2008), Subhan (2012), BaekKyoo (2010), Jeong-Sil Choi (2018), Aparecida (2013), Arwani (2013), Whitley (2012), Elçia (2011), Amaliah (2015), Ans De Vos (2011), dan Wen-Hwa Ko (2012).

Merujuk dari uraian di atas maka, pada disertasi ini dapat dibuat rumusan bahwa, secara teoritis faktor-faktor yang mempengaruhi kematangan karier adalah terdiri dari: kematangan karier, budaya organisasi, religiusitas dan kompetensi.

b. Temuan aplikatif dalam Disertasi ini merupakan bukti empiris dari hasil pengujian antar indikator terhadap variabel dan wawancara secara acak terhadap responden, menunjukkan temuan bahwa, kematangan karier dipengaruhi hal-hal sebagai berikut:

1. Aqidah yang kuat, artinya bahwa pustakawan pada saat menjalani profesi wajib mempunyai keyakinan bahwa: 
a. Allah SWT akan selalu menolong hambaNya,

b. memegang teguh ajaran Islam,

c. dibalik kesulitan pasti ada kemudahan,

d. Allah SWT memberikan ujian sesuai dengan batas kemampuan, dan

e. Agama Islam mengatur seluruh aspek kehidupan.

2. Akses karier berkelanjutan yang tinggi, artinya bahwa seorang pustakawan didalam menjalankan profesinya perlu:
a. mendapat dukungan positif dari kawan non pustakawan,
b. meyakini bahwa profesi pustakawan mempunyai prospek baik di masa depan,
c. mempunyai harapan peran strategis terhadap asosiasi profesi pustakawan,
d. mendapat dukungan penuh dari keluarga, dan
e. mendapat dukungan penuh dari sesama pustakawan di kantornya.

\section{Keterbatasan Studi}

Meskipun penelitian ini telah menganut dan mengikuti kaidah-kaidah studi ilmiah, akan tetapi ada hambatan maka riset ini tidak dapat dikerjakan secara komprehensif, sehingga keterbatasan yang telah diduga sebelumnya dapat dijelaskan sebagai berikut.

a. Bahwa penelitian ini mempunyai variabel-variabel penelitian yang terbatas yakni 2 variabel riset, yang sebenarnya masih ada faktor lain yang dapat dijadikan variabel, misalnya: kepemimpinan profetik, budaya organisasi, kompetensi, motivasi, kepercayaan diri, tunjangan profesi pustakawan, dan lain-lain. Akan tetapi hasil penelitian ini telah memberikan andil empiris dan teoritis terkait fungsi religiusitas, dalam rangka meningkatkan kematangan karier pustakawan.

b. Dalam mencari pengaruh asosiatif variabel, belum dicari pengaruh antara jenis kelamin (gender), masa kerja, tingkat pendidikan, dan umur terhadap kematangan karier.

c. Lokasi penelitian disertasi ini masih terbatas pada Pendidikan Tinggi Keagamaan Islam (PTKI) di DIY yang berkategori universitas, belum melibatkan kategori sekolah tinggi dan institut. Di waktu-waktu mendatang perlu dilakukan penelitian dengan mengikutsertakan pendidikan tinggi di DIY, baik negeri maupun swasta.

\section{E. PENUTUP}

\section{Simpulan}

Dari analisis data dan uji statistik dapat dirumuskan simpulan bahwa:

1. Persepsi Pustakawan Pendidikan Tinggi Keagamaan Islam (PTKI) di DIY terhadap religiusitas (X) oleh responden dipersepsikan dalam kategori sangat tinggi dengan skor 86,67 dan kematangan karier (Y) oleh informan dinilai pada klasifikasi baik dengan nilai 77,82.

2. Persepsi Pustakawan Pendidikan Tinggi Keagamaan Islam (PTKI) di DIY terhadap Religiusitas $(X)$ berpengaruh signifikan terhadap kematangan karier (Y) terdapat nilai pengaruh sebesar 0,292 dengan signifikansi 0,009<0,05, artinya menerima hipotesis.

3. Secaraumum, dalam penelitian inimemberikan kesimpulan bahwa secara teoritik religiusitas berpengaruh terhadap kematangan karier Pustakawan Pendidikan Tinggi Keagamaan Islam (PTKI) di DIY.

\section{Saran}

Masukan dan saran ditujukan kepada: 
pustakawan dan periset secara umum, perpustakaan, kepala perpustakaan, asosiasi profesi, prodi ilmu perpustakaan, pemerintah, dan lain-lain.

4. Responden menilai bahwa ada titik lemah yang mendasar terhadap Religiositas Pustakawan PTKI di DIY pada aspek akhlak karimah antara lain meliputi:

a. Menurut mereka menolong teman dalam memecahkan masalah merupakan hal yang kurang penting.

b. Dalam beramal kepada orang lain, agar dipandang sebagai orang yang dermawan.

c. Ketika melihat batu/duri di tengah jalan yang bisa mencelakai orang, enggan menyingkirkannya.

d. Bersedia menyumbang untuk acara bakti sosial di kantor jika namanya disebutkan di hadapan orang banyak.

5. Responden menilai bahwa ada titik lemah pada Kematangan Karier Pustakawan Pendidikan Tinggi Keagamaan Islam (PTKI) di DIY pada sisi pengembangan profesi dan kegiatan penunjang pustakawan yang terdiri atas:

a. Kemampuan membuat artikel ilmiah pada bidang librarianship.

b. Kemampuan menerjemahkan dan menyadur bahan perpustakaan pada bidang librarianship.

c. Kemampuan menyusunan buku panduan/petunjuk praktis pada kegiatan kepustakawanan.

d. Keaktifan dan peran dalam pertemuan ilmiah (seminar, lokakarya, work-shop, dan yang sejenisnya).

e. Keaktifan dalam keanggotaan organisasi profesi.

6. Kontribusi yang diperoleh dari hasil studi ini adalah:

a. Pertama, memberikan kontribusi kepada ilmu pengetahuan terutama ilmu perpustakaan berupa pola pengembangan profesi untuk mencapai kematangan karier. Terciptanya pola pengembangan profesi dalam upaya meraih kematangan karier pustakawan, memudahkan para ahli dalam memahami proses dinamika kematangan karier pustakawan.

b. Kedua, memberikan kontribusi terhadap disiplin psikologi perpustakaan dan manajemen sumber daya manusia. Psikologi Perpustakaan adalah kajian yang mempelajari perilaku individu dalam konteks interaksi pustakawan dengan pemustaka, interaksi antar pustakawan, pustakawan dengan materi perpustakaan, dan pemustaka dengan koleksi perpustakaan. Pengembangan profesi dalam meraih kematangan karier pustakawan adalah satu tema menarik yang perlu diteliti, mengingat masih terbatasnya kajian di bidang ini.

c. Ketiga, ikut mengembangkan kajian Psikologi Islam. Hal ini karena penelitian ini berkaitan dengan variabel religiusitas, sebuah topik yang sangat menarik perhatian para pengkaji Psikologi Islam. Wacana Psikologi Islam adalah bidang kajian yang berkembang secara signifikan di Indonesia dan beberapa negara Islam dan Barat yang berupaya mengkaji proses dinamis pengaruh religiusitas dan kepemimpinan profetik terhadap perilaku individu. Tema religiusitas, kepemimpinan profetik, kompetensi, dan kematangan karier adalah empat tema penting dalam konteks Psikologi Islam.

d. Keempat, hasil riset ini harapannya dapat menambah dan memperkaya kajian pada 
bidang kematangan karier pustakawan dalam upaya menguji dan mengkaji teori terdahulu, atau bilamana mungkin dapat menemukan teori baru melalui penelitian bertajuk "Pengaruh Religiusitas terhadap Kematangan Karier Pustakawan Pendidikan Tinggi Keagamaan Islam (PTKI) di Daerah Istimewa Yogyakarta".

e. Kelima, hasil studi ini diharapkan dapat menambah wawasan penulis berkaitan dengan faktor-faktor yang mempengaruhi kematangan karier Pustakawan Pendidikan Tinggi Keagamaan Islam (PTKI) di Daerah Istimewa Yogyakarta.

f. Keenam, dengan penelitian ini, hasilnya diharapkan dapat memberikan kontribusi bagi Perpustakaan Pendidikan Tinggi Keagamaan Islam (PTKI) di Daerah Istimewa Yogyakarta, seberapa besar tingkat terukurnya kematangan karier pejabat fungsional pustakawan pada lembaga tersebut.

g. Ketujuh, bagi prodi Ilmu Perpustakaan dapat dipakai sebagai rujukan dalam membuat kurikulum pendidikan yang selaras dengan kebutuhan pasar tenaga kerja.

h. Kedelapan, diharapkan dapat menambah referensi bagi peneliti selanjutnya yang berminat meneliti topik yang sama.

\section{DAFTAR PUSTAKA}

Abdullah, M. A. (2002). Studi Agama: Normativitas atau Historisitas? Yogyakarta: Pustaka Pelajar.

Alawiyah, E. M. L. (2012). Pelatihan Kepemimpinan Kenabian untuk Meningkatkan Komitmen Mengajar Guru di SDIT “H”. Tesis. Yogyakarta: Program Magister Psikologi Profesi FPSB UII.

Alawiyah, E. M. L. (2014). Prophetic Leadership Training To Increase The Teacher's Teaching
Commitment. Jurnal Intervensi Psikologi, 6, 18-33.

Amaliah, I., Aspiranti, T., ,; Purnamasari, P. (2015). The Impact of the Values of Islamic Religiosity to Islamic Job Satisfaction in Tasikmalaya West Java, Indonesia, Industrial Centre. Procedia Social and Behavioral Sciences, 211, 984 - 991. Anshari, E.S. (1987). Agama, Filsafat, dan IImu. Surabaya: Bina llmu.

Chatterjee, S. (2013). A conceptual framework examining the antecedents of career decisiveness using motivation systems theory. International Journal on New Trends in education and Their Implications. 4(4), 31-41.

Dister, N.S. Pengalaman dan Motivasi Beragama. (1994). Yogyakarta: Penerbit Kanisius.

Elçia, M., Sener, E., ,; Alpkan, L. (2011). The Impact of Morality and Religiosity of Employees on Their Hardworking Behavior. Procedia Social and Behavioral Sciences, 24, 1367-1377.

Fitriyaningsih. (2012). Pengaruh Tingkat Religiusitas Terhadap Kinerja Karyawan Dengan Etika Kerja Islami Sebagai Variabel Intervening (Studi Kasus Pada Baitul Maal Wat Tamwil di Yogyakarta). Laporan Penelitian, Tidak Diterbitkan (hlm. 92). Yogyakarta: Fakultas Eknomi UII.

Nashori,F.;;Macharam,R.D.(2002).Mengembangkan kreativitas dalam Perspektif Islami. Yogyakarta: Menara Kudus.

Glock, C.Y.; Stark. (1965), Religion and society in tension. San Francisco: Rand McNally.

Glock, C.Y. , Stark. (1988). Agama: dalam Analisa „Interpretasi Sosiologis. Jakarta: Rajawali.

Gonzalez, M. A. (2008). Career maturity: a priority for secondary education. Electronic Journal of Research in Educational Psychology, 6(16), 749-772.

Hamureu, H., Bozgeyikli, H., ,; Eroglu, S. E. (2009). Career decision making self-efficacy, career 
maturity, and socioeconomic status with turkish youth. Georgian Electronic Scientific Journal: Education Science and Psychology. 1(4), 15-24.

Hasan, B. (2006). Career maturity of indian adolescents as a function of self-concept, vocational aspiration, and gender. Journal of the indian academy of applied psychology. 32(2), 127-134.

Lau, P. L., Low, S. F., „; Zakaria, A. R. (2004). Gender and work: assessment and application of super's theory-career maturity. British Journal of Arts and Social Sciences.

Levinson, E. M. et al. (1998). Six approaches to the assessment of career maturity. Journal of Counseling and Development, 76(4), 475-482.

Lock, R. D.(2005). Taking charge of your career direction: career planning guide, book 15th edition. New York: Thomson Learning, Inc.

Mandayun, N. H. (2015). Pengaruh Religiusitas, Kepemimpinan Transformasional dan Kepemimpinan Transaksional terhadap Kinerja Karyawan Universitas Muhammadiyah Surakarta. Laporan Penelitian, Tidak Diterbitkan (Yogyakarta: Fakultas Eknomi UII.

Moeljono, D. (2003). Budaya Koroporasi. Jakarta: PT Elex Media Komputindo.

Moeljono, D. Delapan Langkah Strategis Mendaki Karier Puncak. Jakarta: Elex Media Komputindo Gramedia.

Nashori, F. (2012). Pemaafan pada Etnis Jawa: Pengaruh Religiositas dan Keterikatan Interpersonal terhadap Pemaafan melalui Perantara Sifat Kebersetujuan dan Sifat Neurotisisme (Studi pada Warga Kota Yogyakarta). Disertasi Tidak Diterbitkan. Bandung: Universitas Padjadjaran.

Ottu, I. F. A. „; Idowu, O. O. (2014). Openness to experience, conscientiousness and gender as personality indicators of career maturity of in-school adolescents in ibadan, Nigeria. European Journal of Educational Studies,. 6(1), $1-12$.

Paloutzian, R.E. (1996). Invitation to the Psychology of Religion. New York: Allyn and Bacon.

Perpustakaan Nasional RI. (2015). Peraturan Kepala Perpustakaan Nasional Republik Indonesia Nomor 11 Tahun 2015 tentang Petunjuk Teknis Jabatan Fungsional Pustakawan dan Angka Kreditnya. Jakarta: Perpusnas RI.

Powell, D. F. „; Luzzo, D. A. (1998). Evaluasting factors associated with the career maturity of high school students. The Career Development Quarterly.47(2), 145-158.

Priastuti, P. W. (2015). Pengaruh Kepemimpinan Profetik dan Motivasi Kerja Islami terhadap Disiplin Kerja Pegawai (Tenaga Pengajar dan Staf) SD X Yogyakarta. Tesis. Yogyakarta: Univer:sitas Islam Indonesia.

Salami, S. O. (2008). Gender, identity status and career maturity of adolescents in Southwest Nigeria. Journal of Social Science. 16(1), 35-49.

Savickas, M. L. (2005). The theory and practice of career construction. In S. D. Brown ; R. W. Lent (Eds.), Career development and counseling: Putting theory and research to work (pp. 42-70). New Jersey: John Wiley „; Sons.

Sekaran, U. (2003). Research Methods for Business: a Skill-Building Approach, 4th ed. New York: John Wiley ; Sos Inc.

Sharf, R. S. (2006). Applying career development theory to counseling 4th ed. Canada:Thomson Corporation.

Shihab, M.Q. (1992). Lentera Hati: Lisah dan Hikmah Kehidupan. Bandung: Mizan.

Simpson, J. (2016). The Hart of the University: Library Link Location on Doctoral Granting Institutions Web pages and Correlation with Research Output. The Journal of Academic 
UNI ib $\begin{aligned} & \text { Jurnal Perpustakaan Vol. } 11 \text { No.1 Tahun 2020: 15-34 } \\ & \text { ISSN 1979-9527 (Printed) ISSN 2715-274x (Online) }\end{aligned}$

Librarianship, 42(5), 503-508.

Sudarsono, B. (2010). Pengembangan Profesi

Pustakawan. Media Pustakawan 17(3), 48-52.

Sungadi. (2016). Tingkat Kepercayaan Diri

Pustakawan Universitas Islam Indonesia Dalam

Menjalani Profesinya. Laporan Hasil Penelitian.

Yogyakarta: DPPM UII.

Sungadi. (2016). Jabatan Fungsional Pustakawan

dan Problematikanya. Libraria Jurnal Ilmu

Perpustakaan, 5(1), 36-38. 